deposits formed a single series, which could be subdivided upon stratigraphical grounds. But although there was no evidence of unconformity between the strata, he thought that the fact of different groups of fossils succeeding each other in the same area showed that those groups existed in neighbouring seas, and had been driven by upheaval of the sea-bottom on which they lived, into the region in which they are found. Hence he maintained that a change in the forms of life is evidence of unconformity in an adjoining area.

Mr. Maw remarked that under the Cambrian rocks at Llanberis there are unconformable beds, which may be the equivalents of the so-called Greenstones of St. David's.

Mr. Hicks admitted that the subdivisions at present in use may need to be modified. He thought that the greatest break is between the Menevian and the Lingula Flags, few species passing from one to the other. He regarded the upper and lower portions of the Tremadoc as really distinct.

\title{
COFRFSPOANDINCF.
}

\section{VOLCANIC ROCKS OF THE LAKE-COUNTRY.}

SrR,-As much interest attaches to the question of the relation of the volcanic rocks of the Lake-country (the Green Slate and Porphyry series) to the older Skiddaw Slates, and as one of us formerly expressed an opinion on the subject contrary to what the subsequent researches of the Geological Survey have made out, it may interest some of your readers to learn that we have lately discovered in Swindale, near Shap, beds of volcanic ash of the Green Slate and Porphyry series clearly interbedded with the Skiddaw Slates, similar to the case discovered by Mr. Aveline near Black Comb.

$$
\begin{aligned}
& \text { J. R. Dakyns, Kendal, } \\
& \text { J. Curfton WaRd, Keswick. }
\end{aligned}
$$

\section{DEEP BORING IN PRUSSIA.}

SIR,-I send you some particulars, with which I have lately been favoured by Professor A. von Koenen, of Marburg, respecting the deep boring made by the Prussian Government Engineers at Sperenberg, abont 25 miles south of Berlin, and noticed by your correspondent J. P. at page 48 of the Geologioal Magazinz for January.

The boring for the first 956 feet (12971 English feet) was mado by manual labour, at a cost of about $£ 1600$.

Several accidents having happened, the borehole was then lined for a depth of 85 feet (115 English feet) with tubes of 15 inches diameter; beyond that, to the depth of 100 feet ( 135 English feet), with 14-inch tubes; and then to $363 \frac{1}{2}$ feet (4931 English feet) with tubes of $12 \frac{1}{2}$ inches diameter.

The length of time occupied in the above-mentioned work was fifteen months-comprised between May, 1867, and July, 1868.

From the depth of 956 feet (12971 English feet), for the remaining distance, the boring was carried on by means of a steam-engine. The length of time consumed in sinking this additional 3095 feet (4255 feet English), comprised between January, 1869, and the 15th September, 1871, was about $31 \frac{1}{2}$ months, or 2 years and 7 months; during which interval several accidents occurred. 